\title{
Implementation of Group Investigation Model Integrated Macromedia Flash on Students' Learning Outcomes
}

\author{
Nelius Harefa $^{1 *}$, Novia Fransisca Dewi Silalahi ${ }^{2}$ \\ ${ }^{1}$ Department of Chemistry Education, Faculty of Teacher Training and Education, Universitas Kristen Indonesia, \\ Indonesia \\ ${ }^{2}$ Chemistry Teacher of SMA Abdi Siswa Bintaro, Tangerang, Indonesia \\ nelius.harefa@uki.ac.id ${ }^{1}$ noviasilalahi19@gmail.com ${ }^{2}$
}

\begin{abstract}
This study aims to determine the implementing of Group Investigation model integrated macromedia flash on students' learning outcomes. The research sample consisted of two classes taken randomly namely the experimental class 1 and the experimental class 2 . The experimental class 1 as a experiment class that is taught by the Group Investigation integrated macromedia flash model and the experimental class 2 as a control class was taught by Direct Instruction model. The design of the study uses the Complete Random Design method. Research data collection was carried out by using research instruments in the form of objective tests and analyzed by a simple Variance Analysis method at a significance level of 0.05 . The research data showed that the average pretest of the experimental class 1 (39.88) was lower than the average of the experimental class 2 (40.56) and the average posttest of the experimental class 1 (79.70) was higher than the experimental class 2 (74.08). Based on research data analysis, it is concluded that there is an influence of the Group Investigation learning model integrated Macromedia Flash on students' learning outcomes in oxidation reduction material, $\mathrm{F}_{\text {count }}(6.55)>\mathrm{F}_{\text {table }}(4.11)$ at the 0.05 significance level.
\end{abstract}

Keywords: group investigation, macromedia flash, learning outcomes

\section{INTRODUCTION}

Learning activities is a process that contains a series of teacher and student activities on the basis of reciprocal relationships that take place in an educational situation to achieve certain goals. Thus, the success or failure of educational goals depends a lot on how the learning process takes place. The learning process will depend on the strategy, model and learning media. Strategies, models, and / or learning media are very effective in stimulating students to understand learning objectives. Applying the right strategies, models and / or learning media will help students in understanding learning material both in the cognitive, affective, and psychomotor areas. One of the problems faced by Indonesian education is that learning models and media are less varied according to the times and the needs of students in the learning process (Silaban, 2015).

The learning process in the classroom is directed at the student's ability to memorize the information he remembers to connect it with daily life. This fact applies to all subjects. Science subjects cannot develop children's ability to think critically and systematically, because thinking strategies are not used properly in every learning process in the classroom (Pardede \& Suyanti, 2016).

Chemistry is a science that belongs to the Natural Sciences family which basically has two components namely the product and process components. Chemistry is not only a collection of knowledge in the form of facts, concepts or principles, but also a process of discovery. Therefore, in the study of chemistry it should not rule out the process of concept discovery (Harefa, 2018). The learning process in the field of science, especially chemistry, must be adapted to a developing curriculum that can accommodate the era of the industrial revolution 4.0. Practicum (or often called practice) is one important part of chemistry that can be created referring to the curriculum to accommodate the developing era. Practicum is very crucial role in learning chemistry, practicum is a place to practice students in proving or discovering new information from the concepts they are learning (Harefa, et al., 
2019). Thus, learning through practicum directly accommodates student-centered learning.

To overcome these problems requires the selection of learning models and learning media that are appropriate to the subject matter in order to improve student learning outcomes (Cahyani \& Hendriani, 2017). The Group Investigation learning model is one of the learning models that can train students to develop the ability to think independently and actively engage students that can be seen starting from the first stage to the final stage of learning (Nadeak, 2018; Pamungkas, 2017). In addition, the Group Investigation learning model is also a learning model that creates interest and stimulates students' curiosity to investigate information privately or together with their group colleagues.

In addition to the right model, supporting media is also needed to increase student enthusiasm, visualization is one way that can be done to concentrate something abstract (Purba et al. 2018; Purba et al. 2015). In the era of informatics visualization developed in the form of moving images (animation) that can be added to sound (audio) (Purba et al. 2019). Audio visual offerings or better known as multimedia makes visualizations more interesting. One of the interesting media is using macromedia flash computer media with animation that helps students see real learning so that they better understand the subject matter (Arwira et al., 2019).

Wildanisani et al, (2015) to increase learning achievement $32.35 \%$ in the first cycle to $64.71 \%$ in the second cycle and (Waruwu, 2013) improve learning outcomes by $71 \%$. Increase learning by $61 \%$. The same thing stated Hariyanti, et al, (2013) can increase student learning achievement to reach $66.67 \%$. Thus, research on the effects of learning needs to be done by using the integrated group investigation model of Macromedia Flash on student learning outcomes.

\section{METHOD}

This research is an experimental study, which the sample of the study consisted of two classes taken randomly (homogeneous and normal classes), namely the experimental class 1 and the experimental class 2 . The research samples were students of XII MIPA 1 and XII MIPA 2 SMA Yadika 9 Bekasi, West Java. The research held on August 2019 - September 2019. In the study, students of class XII MIPA 1 as experimental class 2 and class XII MIPA 2 as experimental class 1 . The experimental class 1 as an experimental class was taught with group Investigation model integrated Macromedia Flash and experimental class 2 as a control class was taught by direct instruction model. Both classes were designed using the Complete Randomized Design method, presented in Table 1.

Table 1: Research Design

\begin{tabular}{|l|l|l|l|}
\hline Class & Pretest & Treatment & Posttest \\
\hline Experiment 1 & $\mathrm{X}_{1}$ & $\mathrm{~A}$ & $\mathrm{X}_{2}$ \\
\hline Experiment 2 & $\mathrm{Y}_{1}$ & $\mathrm{~B}$ & $\mathrm{Y}_{2}$ \\
\hline
\end{tabular}

A is treatment with Group Investigation model integrated Macromedia Flash.

B is treatment with Direct Instruction model.

The research instrument used to collect research data is an objective test that has been valid and reliable, meets the requirements for the level of difficulty of the questions, and the test differentiator. Analysis of the research data was performed using a simple analysis of variance at a significance level of 0.05 .

\section{RESULT}

The experimental class 1 was taught with Group Investigation model integrated Macromedia Flash and the experimental class 2 was taught with the Direct Instruction model. A pretest was first conducted to determine the students' prior ability of oxidation reduction material. After knowing the initial data of students' abilities, then treatment is given for each class. At the end of the material, a posttest is given to determine the student's final ability to reduce oxidation material. Based on the results of the study, the pretest and posttest results of the two experimental classes are shown in Table 2.

Table 2: Pretest and Posttest Data for Each Experiment Class

\begin{tabular}{|l|l|l|l|l|l|l|}
\hline \multirow{2}{*}{ Class } & \multicolumn{2}{|l|}{ Pretest } & \multicolumn{3}{l|}{ Posttest } \\
\cline { 2 - 7 } & $\mathrm{X}_{\min }$ & $\mathrm{X}_{\max }$ & Average & $\mathrm{X}_{\min }$ & $\mathrm{X}_{\max }$ & Average \\
\hline $\mathrm{E}-1$ & 30 & 42 & 39.88 & 72 & 88 & 79.70 \\
\hline $\mathrm{E}-2$ & 30 & 42 & 40.56 & 71 & 87 & 74.08 \\
\hline $\mathrm{N}$ & 20 & 20 & \\
\hline
\end{tabular}

The highest pretest result for experimental class 1 is 42 while the lowest value is 30 . Similarly, the experimental class 2, the highest value is 42 and the lowest is 30. In general, the pretest value of experimental class 1 is lower than the pretest value of experimental class 2 with a mean difference average value of 0.68 . As for the posttest score, the average value of experimental class 1 is higher than the experimental class 2 with a difference in average value of 5.72 . 
The highest posttest in experimental class 1 was 88 and the lowest was 72 . While the highest posttest in experimental class 2 was 87 and the lowest was 71 . Thus, the prior ability of experimental class 1 students is lower than the prior ability of experimental class 2 students. However, by giving treatment that is taught with Group Investigation model integrated Macromedia Flash, the final ability of experimental class 1 students is higher than the final ability of experimental class 2 which is taught with Direct Instruction model.

Based on Table 2, the descriptive statistics of the students learning outcomes of each experimental class can be summarized on Table 3 .

Table 3. Descriptive Statistics of Students' Learning Outcomes for Each Experiment Class

\begin{tabular}{|l|l|l|l|l|l|l|l|}
\hline \multirow{2}{*}{ Class } & \multicolumn{3}{|l|}{ Pretest } & \multicolumn{2}{l|}{ Posttest } & X2- \\
\cline { 2 - 8 } & $\mathrm{X}_{1}$ & $\mathrm{~S}$ & $\mathrm{~S}_{2}$ & $\mathrm{X}_{2}$ & $\mathrm{~S}$ & $\mathrm{~S}_{2}$ & X1 \\
\hline $\mathrm{E}-1$ & 39.88 & 5.82 & 33.87 & 79.70 & 6.95 & 48.30 & 39.82 \\
\hline $\mathrm{E}-2$ & 40.56 & 5.80 & 33.64 & 74.08 & 4.87 & 23.71 & 33.52 \\
\hline
\end{tabular}

$\mathrm{X}_{1}$ is the pre-test average value of each experimental class

$\mathrm{X}_{2}$ is the post-test average value of each experimental class

Based on the table, there are differences between the average pre-test and post-test scores of each experimental class. For the experimental class 1, there was an increase in the average value between the posttest and pre-test by 39.82. As for the experimental class 2 , there was an increase in the average value between post-test and pre-test by 33.52 .

\section{DISCUSSION}

The implementation of learning models in both experimental classes was carried out by testing the hypothesis of a simple variance analysis $\left(\mathrm{F}_{\text {count }}\right)$. Test criteria if $F_{\text {count }} \geq F_{\text {table }}$ at the real level of 0.05 and $\mathrm{db}$ 39. Data from the analysis of variance test results are shown in Table 4.

Table 4. Analysis of Variance Test Result

\begin{tabular}{|l|l|l|l|}
\hline \multicolumn{2}{|l|}{ Class } & $F_{\text {count }}$ & $\mathrm{F}_{\text {table }}$ \\
\hline Experiment 1 & Experiment 2 & & \\
$\mathrm{X}=79.70$ & $\mathrm{X}=74.08$ & \multirow{3}{*}{6.55} & \multirow{2}{*}{4.11} \\
$\mathrm{SD}=6.95$ & $\mathrm{SD}=4.87$ & & \\
$\mathrm{~S} 2=48.30$ & $\mathrm{~S} 2=23.71$ & & \\
\hline
\end{tabular}

Based on $\mathrm{F}$ distribution data obtained Ftable $=4.11$, while based on calculations obtained $F_{\text {count }}=6.55$ so that the price of $F_{\text {count }} \geq F_{\text {table }}$ at a significance level of 0.05 . Thus there is the influence of Group Investigation model integrated Macromedia Flash on students' learning outcomes in the oxidation reduction material.

Group Investigation is the most complex and most difficult cooperative learning model to implement. Different from other learning models, the Group Investigation learning model involves students in the planning stage of both the topic being studied and how the investigation progresses and emphasizes the participation and activities of students to find themselves (information) that supports the subject matter to be learned through available materials.

The Group Investigation learning model using macromedia flash can help students more easily understand chemical materials specifically on the subject of reduction and oxidation reactions because students see clearly the relationship of learning material with daily life, so that the material is more easily understood.

The Direct Instruction Model is an information learning model with a question and answer method and assignments. In the direct learning model students are more passive because the teacher is a source of information.

\section{CONCLUSION}

The Group Investigation learning model using macromedia flash can help students more easily understand chemical materials specifically on the subject of reduction and oxidation reactions because students see clearly the relationship of learning material with daily life, so that the material is more easily understood. Research data shows that the average pretest value of experimental class 1 (39.88) is lower than the average pretest value of experimental class 2 (40.56) and the average posttest value of experimental class $1(79.70)$ is higher than the average posttest score of the experimental class 2 (74.08). Thus, the initial ability of students in experimental class 1 is higher than the initial ability of experimental class 2 students. By implementing the Macromedia Flash-based Group Investigation learning model, the final ability of experimental class 1 students is higher than the final ability of experimental class 2 students. 


\section{REFERENCES}

1. Arwira, T. M., Suyanti, R. D., \& Saragi, D., 2019. The Effect of Problem Based on Learning Models Using Macromedia Flash and Motivation Against Student Learning Outcomes on Environmental Pollution Materials. Budapest International Research and Critics Institute (BIRCI-Journal): Humanities and Social Sciences, 2(4), 326-333.

2. Cahyani, R., \& Hendriani, Y., 2017. Students' multimedia-assisted scientific inquiry ability on the material of reproductive cells. Jurnal Pendidikan IPA Indonesia, 6(2), 265-270.

3. Harefa, N., 2018. Hubungan Motivasi Belajar Terhadap Keterampilan Pemecahan Masalah Siswa Pada Metode Praktikum. Jurnal Selaras: Kajian Bimbingan dan Konseling serta Psikologi Pendidikan, 1(1), 28-38.

4. Harefa, N., Silalahi, N. F. D., Sormin, E., Purba, L. S. L., \& Sumiyati, S., 2019. The difference of students' learning outcomes with project based learning using handout and sway Microsoft 365. Jurnal Pendidikan Kimia, 11(2), 24-30.

5. Nadeak, B., 2018. Students' critical thinking skill and its relation with knowledge and experience at medical faculty christian university of indonesia. International Journal of Scientific Engineering and Research (IJSER), 6(1), 100-106.

6. Nadeak, B., \& Naibaho, L. (2019, November). Investigating the effect of learning multimedia and thinking style preference on learning achievement on anatomy at Universitas Kristen Indonesia. In Journal of Physics: Conference Series (Vol. 1387, No. 1, p. 012116). IOP Publishing.

7. Pamungkas, M. S. H., Mulyani, S., \& Saputro, S., 2017. Penerapan model pembelajaran poe dengan metode praktikum untuk meningkatkan rasa ingin tahu dan prestasi belajar kimia siswa. Jurnal Penelitian Pendidikan, 20(1), 46-60.

8. Pardede, E., \& Suyanti, R. D., 2016. Effect of Guided Discovery Learning Model Based Collaboration with Flash Media on Science Process Skills. Jurnal Pendidikan Fisika, 5(1), 12-17.

9. Purba, D. N., Damanik, M., Silaban, S., \& Simatupang, L., 2018. The difference of student's activities and learning outcome with problem based learning using macromedia flash and handout. Jurnal Pendidikan Kimia, 10, 403-408.

10.Purba, F. J., Muchtar, Z., \& Silaban, R., 2015. Pengembangan penuntun praktikum kimia sesuai model pembelajaran penemuan dan berbasis proyek. Jurnal Penelitian Bidang Pendidikan, 21(1), 21-28.

11.Purba, L. S. L., Sormin, E., Harefa, N., \& Sumiyati, S., 2019. Effectiveness of use of online games kahoot! chemical to improve student learning motivation. Jurnal Pendidikan Kimia, 11(2), 57-66.

12. Sari, D. K., Supahar, S., \& Ralmugiz, U., 2018. The influence of android-based isomorphic physics (Forfis) application on analogical transfer and selfdiagnosis skill of students at SMA Negeri 3 Kupang. Jurnal Pendidikan IPA Indonesia, 7(2), 154-161.

13. Silaban, S., 2015. Pengaruh model pembelajaran Contextual Teaching and Learning (CTL) terhadap hasil belajar siswa pada pokok bahasan sistem koloid. Jurnal Title, 7(01).

14. Tyas, E. H., \& Naibaho, L. (2021). HOTS Learning Model Improves the Quality of Education. International Journal of ResearchGRANTHAALAYAH, 9(1), 176-182.

15. Wardani, S., Lindawati, L., \& Kusuma, S. B. W., 2017. The development of inquiry by using androidsystem-based chemistry board game to improve learning outcome and critical thinking ability. Jurnal Pendidikan IPA Indonesia, 6(2), 196-205.

16. Waruwu, F., 2013. Pengaruh Pembelajaran Model Kooperatif Tipe Group Investigation (GI) Menggunakan Media Handout Terhadap Hasil Belajar Kimia Siswa Pada Pokok Bahasan Sistem Koloid, Skripsi, FMIPA, UNIMED, Medan.

17. Wildani., Elfi Susanti., Haryono., 2015. Penerapan Model Pembelajaran Group Investigation (GI) Untuk Meningkatkan Keterampilan Proses dan Prestasi Belajar Siswa Pada Materi Laju Reaksi kelas XI SMA Negeri 2 Karanganyar Tahun Pelajaran 2013/2014. Jurnal Pendidikan Kimia (JPK), 4(1): 151-15 